\title{
References
}

Centre for International Economics (CIE) (1994), The $\$ 12000$ used car tanif: an impediment to the use of unleaded fuel, Canberra.

Commonwealth of Australia (1993), Budget Speech and Statements I and 2 of Budget Paper No. I 1993-94, AGPS, Canberra.

Parliament of the Commonwealth of Australia (1992), Reports by Senate Standing Committees on Consideration of Bills, AGPS, Canberra.

David Pearce is Principal Policy Analyst with the Centre for International Economics, Canberra.

\section{The Virtue of Cooperation: Australia's Volunteer Fire Brigades}

\author{
Shaun Kenaelly
}

7 The bush fires that erupted in New South Wales in early 1994 reminded many of us that most nural and outer suburban fire-fighting in the country is undertaken by volunteers. There is central coordination, but the ordinary activities of training, fire-prevention and fund-raising belong to the brigades. These are composed entirely of residents, who give freely of their time and labour to these community services. They are the first to respond with their close district knowledge. Only long-standing residents know the directions from which a bushfire is most likely to come; where back-burning might stop it; what sudden turns it may take, whistling through gullies. There is a direct sense of place.

Brigades also respond to house-fires, storm damage, and motor accidents. They are very closely integrated into the life of a township. In the fire-prone Blue Dandenongs outside Melbourne, two brigades sponsor local Carols by Candlelight and have done so for years. Another sends Santa around on the truck to distribute lollies to children. One sponsors an annual art-show; another (with Rotary) a big town fete. That is for fund-raising, of course; another brigade holds a formal dinner-dance. Then there are the weekly street-stalls where ladies from the auxiliary sell cream cakes. One brigade draws up its vehicles outside the fire-station on Anzac Day, as a salute to the RSL parade marching by. On 11 November the siren is sounded to mark beginning and end of the two-minute silence. The composition of the fire brigade would be interchangeable with that of the football team and the roll of honour on the Anzac memorial — and, for that matter, the Surf Lifesaving Club of a coastal town. 
Sir Arthur Streeton retired to Olinda, in the Blue Dandenongs, and from there wrote in the Argus (30 January 1932):

We have splendid bands of resourceful men, most of them war veterans, who, when fire appears, abandon their daily labour or business and render yeoman service in saving homes and townships. This hard and unselfish work has small reward. It is done for nothing.

Henry Bolte, later Premier of Victoria, paid a similar tribute in his maiden speech in theVictorian Parliament on 17 December 1947. He was president of the Meredith brigade and a former lieutenant. It was a year of severe fire danger. The brigade knew what to do and how to act. It was local: graziers and landowners supported it and it was an effective unit: "The people were interested in it, and they knew that the money they subscribed was wisely spent. They were supporting it on their own behalf and were allowed to use their own judgement' He complained of a new permit system that restricted burning-off, supposedly in the interest of safety (unlike modern restrictions, which are designed to mitigate the so-called greenhouse effect). He noted the absurdity of forbidding landowners to clear fire-breaks for their own safety on their own land. Worse, public authorities were under no such restraint:

To show how farcical the position is I would point out that there are brigades with effective equipment and plenty of man power, but without proper authority, while on the other hand there are the railway people, who burn any day and all day, and incidentally have a two-foot break and a man with a knapsack pump to stop a fire if it gets away. Furthermore, the railways have bumed off on a proclaimed day. They are a law unto themselves. The land owner and the fire brigades in the country are not permitted to do such things.

Splendid stuff. Yet Streeton was perhaps wrong about the small reward, since cooperative endeavour is itself a joy and grants a substantial yield in fellow-feeling and in extension of the richness in social and community life.

The virtue of cooperation is a curiously underplayed theme in liberal thought. In The Fatal Conceit, F. A. Hayek is dismissive, merely noting in passing that ' $\mathrm{Co}$ operation makes sense in a small group'. But it is not hard to see why. For over a century liberals have been in the business of defending competition against the routine charge that cooperation is better. Historically, the term has belonged to the language of socialism: communitarians, utopians, anarchists. There is also a substantial Roman Catholic tradition. But liberals are also conscious of the limitations of state power and this is why any neglect might seem a curious thing.

A useful bridge is provided by the neglected work of the Russian anarchist, Prince Peter Kropotkin (1842-1921), most especially his Mutual Aid (1902) and Fields,

1

Victorian Parliamentary Debates, 17 December 1947, p.431. 
Factories and Workshops (1898). Interestingly, the essays in these books were published first in the English liberal journal, The Nineteenth Century, and are so addressed. Kropotkin seeks utopian ends; but let us put these aside, as many of his contemporary readers would have done. I shall draw from Mutual Aid.

Cooperation, for Kropotkin, is the thing. Against Hayek he would certainly have argued that if mutual-aid activities were the province of small groups, then society was indeed full of them - to which extent, Hayek's concept of 'extended order' would have made perfect sense to him. He pointed to the formation of the Lifeboat Association, with several hundreds boats around the coast: 'and it would have twice as many were it not for the poverty of the fishermen, who cannot afford to buy lifeboats'. He referred to friendly societies; Oddfellows; the myriad societies organised for what we might regard as hobbies, but which prove essential for any sure conception of the good life: 'cricket, football, nine-pins, pigeon, musical or singing clubs'. Nor are such associations inevitably small-scale. The German Alpine Clubs had over 100,000 members in his day. They were responsible for mapping, making trails, building refuge huts: 'very useful work, which large associations alone could do properly'. Better, such unions were essentially classless. Kropotkin seems to have missed the Red Cross, which was international in character. But he referred to the creation of the Universal Postal Union as a practical instance of cooperation between nations. Kropotkin was a geographer and knew that an awful lot of scientific work gets done this way. Serious ornithological surveys, for example, are next to impossible without the enthusiastic assistance of bird observer clubs.

Kropotkin deserves a reading. How might a discussion advance? The voluntary principle is essentially cooperative; friendly; self-rewarding and extensive. There is an intangible 'bush sense', as in the example of volunteer fire-brigades. They know the country where government, often, does not. More, such people have their feet on the ground; romantic bush-fanciers do not (though they do know how to band together into lobbies and do so extremely effectively). But if natural disasters bring out the best in people, they also help to sort out common sense from wishful thinking. David Clark put it simply enough in the Australian Financial Review (10 January 1994): 'The fires also exposed the silliness of our long-standing "they will look after it" philosophy. "They" didn't look after it.'

\section{S. P. Kenaelly is a private scholar.}

